\title{
Effect of Solution pH to Indigosol Blue Adsorption on Humic Acid Isolated from Kalimantan Peat Oil
}

\author{
Gita Citra Santi*, Maya Rahmayanti** \\ Chemistry Department, Faculty of Science and Technology, UIN Sunan Kalijaga \\ J1. Marsda Adisucipto No. 1 Yogyakarta 55281, Indonesia. Telp. (0274) 558254. Fax. (0274) 586117 \\ Email: gitaci57@gmail.com*, m.rahmayanti@ymail.com ${ }^{* *}$
}

\begin{abstract}
There has been study on the isolated of humic acid and its interaction with indigosol blue. The objectives of study were to isolate humic acid from Kalimantan peat soil and to study $\mathrm{pH}$ optimation indigosol blue on humic acid. Isolated of humic acid using alkali extraction method with $\mathrm{NaOH}$ as solvent and precipitated with $\mathrm{HCl}$. Humic acid was characterized using FTIR spectroscopy to determine functional group. Based on the result FTIR characterization, adsorption of humic acid was found in the wave number $3140,15 \mathrm{~cm}^{-1}$ which show the vibration of $-\mathrm{OH}, 2924,09 \mathrm{~cm}^{-1}$ show vibration of aliphatic $-\mathrm{CH}, 1705 \mathrm{~cm}^{-1}$ show vibration $-\mathrm{C}=\mathrm{O} \mathrm{of} \mathrm{COOH,} 1627,92 \mathrm{~cm}^{-1}$ show vibration of $\mathrm{C}=\mathrm{C}$ aromatic and $1226,73 \mathrm{~cm}^{-1}$ indicate of $-\mathrm{OH}$ and $\mathrm{CO}$ from $-\mathrm{COOH}$. Based on the result of study, $\mathrm{pH}$ optimation of indigosol blue at $\mathrm{pH} 5$.
\end{abstract}

Keywords: Adsorption, Dyestuff, Humic acid, Indigosol blue, Peat soil

\section{INTRODUCTION}

Batik industry began to grow rapidly starting since UNESCO set batik as a world cultural heritage on October 2, 2009. This is potential that must be improved. The benefits of it was to improve the economy and reduce unemployment, while maintaining the sustainability of batik as a cultural symbol in Indonesia. On the side of usefulness, there was a serious problem, namely liquid waste. In these various processes, waste that was highly damaging to the environment was the coloring process waste because it involves dyes that contain various organic compounds. Dyestuffs are difficult to degrade and difficult to dissolve in water.

Indigosol blue was one of the most soluble and brightly colored dyestuffs. Indigosol blue is often used by batik industry as one of materials used for the dyeing process to produce colors on batik cloth. The problem was that dyeing dense dyes and containing high concentrations of chemicals directly discharged into the environment without first treatment will pollute the environment.

Waste color treatment methods are coagulation and flocculation, ozonation, electro-chemistry, decolorization and adsorption [1], oxidation and photocatalysis [2]. The ozonation method has a disadvantage because it requires high costs and was difficult to implement in the community [4]. The adsorption method has been used to remove dyes in the waters and can turn into non-hazardous compounds. Adsorption usually occurs on the surface of solids which are rich in functional groups $-\mathrm{OH},-\mathrm{NH},-\mathrm{SH}$ and $-\mathrm{COOH}$ [5]. One of the potential adsorbents to reduce and eliminate dyes was humic acid contained in the soil [6], [7], [8]. Humic acid has an abundance of $-\mathrm{COOH}$ and $-\mathrm{OH}$ groups which can reduce the concentration of dyes in liquid waste. Dyestuffs that are often used in the batik industry one of them was indigosol blue.

\section{MATERIALS AND METHODS}

The chemicals used were $\mathrm{NaOH}, \mathrm{NaCl}, \mathrm{HCl}, \mathrm{HF}$, humic acid, $(\mathrm{Ba}(\mathrm{OH}) 2)$ and $\mathrm{Ca}(\mathrm{CH} 3 \mathrm{COO}) 2$ solution. The equipment used included whatman paper, $\mathrm{pH}$ meter, shaker, FTIR, Spectrophotometer UV-VIS and Scanning Electron Microscopy (SEM).

This method of isolating peat soils refers to method suggested by International Humic Substances Society (IHSS), which was alkaline extraction. Dissolved with $\mathrm{NaOH}$ and precipitated with HCL. Purification by adding 1:1 HCl-HF. Determination of total acidity and carboxylic groups of humic acid using potentiometric titration method was carried out. Determination of optimum $\mathrm{pH}$ was carried out with variations in $\mathrm{pH} 4,5$, 6,7 and 8 .

\section{RESULTS AND DISCUSSIONS}

Humic acid in this study was isolated from Kalimantan peat soil. This method of isolating peat soils refers to methods suggested by the International Humic Substances Society (IHSS), which form alkaline extraction. Humic acid dissolves in $\mathrm{NaOH}$ for Nahumic salts, easily dissolves in air. Humic acid was precipitated with $0.1 \mathrm{M} \mathrm{HCl}$ to $\mathrm{pH} 1$ Since humic acid does not dissolve in acids, the acidity was higher, the more deposits are obtained. The precipitation process was carried out by adding $0.1 \mathrm{M} \mathrm{HCl}$, the humic acid obtained was purified with humic acid with $0.1 \mathrm{M}$ : HF 
$0.3 \mathrm{M} \mathrm{HCl}$ solution (1:1) and carried out twice to remove inorganic compounds, especially silica.

Table 1. Comparison of interpretation of wavenumber IR spectra of Stevenson humic acid and this study.

\begin{tabular}{|c|c|c|}
\hline \multicolumn{2}{|c|}{ Humic uptake $\left(\mathrm{cm}^{-1}\right)$} & \multirow[t]{2}{*}{ Vibration type } \\
\hline $\begin{array}{l}\text { Stevenson } \\
\text { (1994) }\end{array}$ & This Research & \\
\hline 3400 & 3410,15 & Stretching vibration -OH \\
\hline 2940-2900 & 2924,09 & $\begin{array}{l}\text { Stretching vibration }-\mathrm{CH} \\
\text { alifatik }\end{array}$ \\
\hline $1725-1720$ & 1705,07 & $\begin{array}{l}\text { Stretching vibration } \\
-\mathrm{C}=\mathrm{O} \text { from } \mathrm{COOH}\end{array}$ \\
\hline 1610 & 1627,92 & $\begin{array}{l}\text { Stretching vibration } \mathrm{C}=\mathrm{C} \\
\text { aromatic, helping } \\
\text { asymmetry } \mathrm{k}-\mathrm{C}=\mathrm{O} \text { in- } \\
\mathrm{COO}\end{array}$ \\
\hline 1250 & 1226,73 & $\begin{array}{l}-\mathrm{OH} \& \mathrm{C}-\mathrm{O} \text { from - } \\
\mathrm{COOH}\end{array}$ \\
\hline
\end{tabular}

According to Stevenson [8], humic acid has major functional groups such as -OH phenolate, -OH carboxylate and - $\mathrm{COOH}$. Widened and strong absorption at a wave number of $3410 \mathrm{~cm}^{-1}$ in humic acid which shows a stretched -OH vibration and indicates the presence of hydrogen bonds. The peak at wave number $2924.09 \mathrm{~cm}^{-1}$ in humic acid shows aliphatic - $\mathrm{CH}$ stretching vibration. The appearance of the absorption peak at wave number $1705.07 \mathrm{~cm}^{-1}$ shows the stretch vibration of $-\mathrm{C}=\mathrm{O}$ from $\mathrm{COOH}$ and ketones. Peak at wave number $1627.92 \mathrm{~cm}^{-1}$ was aromatic $\mathrm{C}=\mathrm{C}$ absorption and asymmetric stretching vibration $\mathrm{C}=\mathrm{O}$. The peak at wave number $1226.73 \mathrm{~cm}$ ${ }^{1}$ was the stretching vibration of C-O. IR spectra of humic acid as a result of this study are in accordance with Stevenson [8] which was known that humic acid has absorption at wave numbers $3400-3300 \mathrm{~cm}^{-1}$ of $\mathrm{H}$ bonds from $\mathrm{OH}$ compounds, 2940-2900 $\mathrm{cm}^{-1} \mathrm{CH}$ aliphatic, 1725-1720 $\mathrm{cm}^{-1}$ bond $\mathrm{C}=\mathrm{O}$ from $\mathrm{COOH}$ and ketone compounds, $1610 \mathrm{~cm}^{-1} \mathrm{C}=\mathrm{C}$ aromatic or $\mathrm{H}$ bonds from $\mathrm{C}=\mathrm{O}$ ketones and $1250 \mathrm{~cm} 1 \mathrm{CO}$ and $\mathrm{OH}$ from $\mathrm{COOH}$.

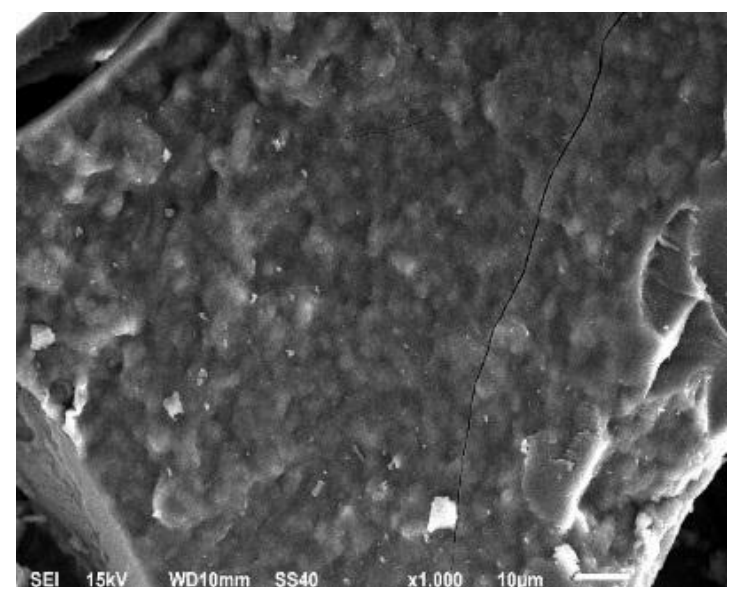

Figure 1. Results of AH characterization using SEM.
In (Figure 1.) the morphological shape of adsorbent of humic acid from the result of isolation has an uneven texture, almost the entire surface has a cavity. The distance between particles looks tight and the cavity was not deep enough so the surface texture looks smooth. Nonetheless, the cavity on surface of humic acid produced by isolation allows for an absorption to occur, where the solution will meet surface of the humic acid from insulation and fill the empty cavity so there was an interaction between humic acid adsorbent and indigosol blue solution.

One factor that affects adsorption was $\mathrm{pH}$. $\mathrm{pH}$ variation was carried out to determine the optimum $\mathrm{pH}$ conditions of the adsorption of humic acid to the adsorption of indigosol blue dyestuff. $\mathrm{pH}$ conditions result in changes charge distribution on adsorbent of humic acid and indigosol blue as a result of protonation and deprotonation reactions of functional groups. In (Figure 2.) it was known that adsorption at an acidic $\mathrm{pH}$ was greater than the alkaline $\mathrm{pH}$ because the adsorbent will dissolve at an alkaline $\mathrm{pH}$.

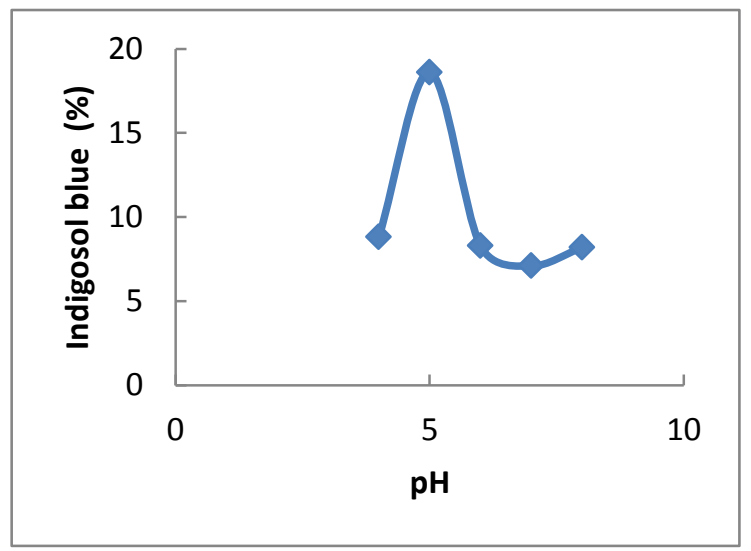

Figure 2. Graph of the relationship between indigosol blue dyes adsorbed (\%) vs. pH.

In this study the $\mathrm{pH}$ variation starts at $\mathrm{pH} 4$ because the acidic $\mathrm{pH}<4$ structure of the indigosol blue solution will be damaged due to breakdown of the active group from indigosol blue dyestuff. In addition, at low $\mathrm{pH}$ $(<3)$ humic acid tends to aggregate due to the formation of strong hydrogen bonds. It can be seen that at acidic conditions, humic acid can adsorb indigosol blue well and optimally at $\mathrm{pH} 5$ with adsorption percentage of $18.6 \%$. That was, the adsorbent of humic acid was able to adsorb the solution of indigosol blue until its concentration was reduced by $18.6 \%$ from its initial concentration before adsorption. In this condition, deprotonation will occur and then when the adsorbent of humic acid was added to dye solution, the surface of humic acid will undergo protonation first followed by electrostatic interactions which cause transfer of dyes in the solution to the protonated humic acid surface. Under low $\mathrm{pH}$ conditions there was neutralization of the negative charge on the surface of humic acid which 
increases protonation and results in increased adsorption. The adsorption mechanism of indigosol blue on humic acid was caused by hydrogen bonds through the electrostatic interaction of $\mathrm{H}$ atoms from humic acid binding to $\mathrm{O}$ atoms.

\section{CONCLUSIONS}

Humic acid was isolated using an alkali extraction method. Characterization results with FTIR showed absorption bands at wave numbers $3140.15 \mathrm{~cm}^{-1}$, $2924.09 \mathrm{~cm}^{-1}, 2337.72 \mathrm{~cm}^{-1}$ and $1705 \mathrm{~cm}^{-1}$. The adsorption process has an optimum $\mathrm{pH}$ of 5 .

\section{ACKNNOWLEDGEMENTS}

Thank to the supervisor who always directs and motivates the writer.

\section{REFERENCES}

Chen, R.P., Yin, L.Z., Lian, F.Z., Xiao, Y.W., Jian, Q.C., Ai, J.M. dan Wi,. M.J. 2015. Lead (II) and Methylene Blue Removal Using a Fully Biodegradable Hydrogel Based on Starch Immobilized Humic Acid. Chemical Engineering Journal

Hashemian, S., Sadeghi, B. dan Mangeli, M. 2014. Hydrotermal Synthesis of Nano Cavities of Al-MCF for Adsorption of Indigo Carmine from Aqueous Solution. Journal of Industrial and Engineering Chemistry.

Lesbani, A., Miksusanti dan Setiawati, Y. 2002. Studi Interaksi Zat Warna Tekstil Auramin dengan Asam Humat Dari Tanah Gambut. Jurnal Penelitian Sains. ISSN: 1410-7058

Matis K. A. 1980. Treatment of industrial liquid wastes by electrofloatation. Water Pollution Control

Mohadi, Risfidian., Nurlwasa H., Sri Juari S., dan Narsito. 2008 Karakterisasi Asam Humat dari Gambut Indralaya, Ogan Ilir Sumatera Selatan. Jurnal Penenelitan Sains. 411-420

Ramesh, T.N., Kirana, D.V., Ashmini,A. dan Manasa. T.R. Calcium Hydroxide as Low Cost Adsorbent for The Effective Removal of Indigo Carmine Dye in Water. Journal of Saudi Chemical Society. 2017. 21, 165-171.

Stumm,W dan Morgan, J.J.1996. Aquatic Chemistry 3th. New York: John Wiley \& Sons

Stevenson, F.J.1994. Humus Chemistry: Genesis, Composition, Reactions. New York: John Wiley \& Sons

V. Prigione, G.C. Varese, L. Casieri dan V.F. Marchisio Biosorption of Simulated Dyed Effluents by Inactivated Fungal Biomasses. Bioresource Technology. 2008. 99, 3559-3567.

Waksman, S. A. 1952. Soil Microbiology. New Work: John Willey and Sons. 
THIIS PAGE INTENTIONALLY LEFT BLANK 